\title{
Early biochemical changes in plasmocid myopathy
}

\author{
PAULINE MONRO \\ From the Department of Chemical Pathology, Guy's Hospital Medical School, \\ London
}

Interpretation of biochemical abnormalities in diseased muscle is usually complicated by the presence of non-muscle components, reactive white cells, collagen, and fat, which cannot be separated satisfactorily and which therefore make a varying and unknown contribution to the results. The use of an acute, reproducible, chemically induced muscle disorder overcomes this problem. Plasmocid (8-(3-diethylaminopropylamino) 6-methoxyquinoline), selectively produces reversible focal necrosis in rat skeletal and cardiac muscle, the first structural changes appearing eight hours after injection. It is therefore possible to obtain muscle in which no structural changes are yet apparent, but in which it is likely that biochemical changes leading to necrosis are occurring.

Plasmocid was synthesized as an anti-malarial (Fourneau, Tréfouel, Bovet, and Benoit, 1931) but has been of very limited use because of toxic effects. Structural changes after plasmocid in experimental animals have been found only in the central nervous system (Wiselogle, 1946) and in muscle (Hicks, 1950; Adams, Denny-Brown, and Pearson, 1962). In skeletal muscle focal loss of actin filaments and $Z$ bands at six to eight hours are the first changes preceding local necrosis (Price, Pease, and Pearson, 1962), whereas in cardiac muscle mitochondrial abnormalities are seen first at this time. Intense infiltration of necrotic muscle with white cells starts at eight to 10 hours, nuclear regeneration is seen at 24 to 48 hours (Pearson in Adams et al., 1962), and ensuing recovery is complete by four weeks.

There have been no histochemical studies on skeletal muscle after plasmocid and the only previous biochemical determination was by Goyer, Yin, and Bowden (1964), who showed that six to eight hours after injection the taurine content of necrosing muscle was unchanged, although serum and urine levels increased, as did serum glutamicoxaloacetic tramsaminase (GOT) (Bowden and Goyer, 1962).

In cardiac muscle Bajusz and Jasmin (1963) using histochemical techniques found that, preceding structural changes after plasmocid, a patchy loss of glycogen from muscle fibres occurred and there were some areas of decreased 5-nucleotidase activity in capillary walls. All other changes shown by them and other workers occurred later and accompanied the necrosis. These later changes were similar to those produced by venous occlusion, consisting of a decrease in oxidative enzymes in degenerating areas accompanied by an increase in lactic dehydrogenase. A decrease in succinic dehydrogenase reported by Wachstein and Meisel (1955) at 22 hours after plasmocid was confirmed by Balogh, Prágay, and Hoyt (1967), who showed that at 24 hours the intramitochondrial enzymes, cytochrome oxidase and succinic dehydrogenase, no longer stained as discrete punctate rows, but became coarse and irregular, a change corresponding with alteration in mitochondrial structure previously noted in heart. Biochemical determination of these enzymes showed a decrease in activity at 24 hours which continued for three days and thereafter returned to normal.

The aim of the present investigation was to determine any biochemical change occurring in rat skeletal muscle within the first few hours after injection of plasmocid. Diaphragm was examined, since Hicks and other workers had shown that not all skeletal muscles are equally affected by plasmocid, but that diaphragm showed histological changes in most rats. The observation of these workers that the muscles which are most in use, the masseter, diaphragm, and external ocular muscles, are those most frequently damaged after plasmocid, suggests that plasmocid may selectively affect a biochemical process called into action during muscle activity. This is supported by the findings of Bajusz, Jasmin, and Mongeau (1964) that the distribution of the lesion in skeletal muscle produced by plasmocid can be altered by exercise immediately before and after the plasmocid injection; those muscles which are most active showing an increased frequency of structural damage.

Since glycolysis is an important source of energy for muscular contraction, it was decided to examine first the rates of glycolysis in diaphragm, both aerobically (Warburg technique) and anaerobically (Mommaerts, Illingworth, Pearson, Guillory, and 
Seraydarian, 1959). These preliminary experiments on pairs of plasmocid and saline injected rats showed that there was no significant difference either in the rate of anaerobic glycolysis, measured in six pairs two hours after injection, or in the rate of aerobic glycolysis measured at two hours (14 pairs) five hours (nine pairs) six hours (four pairs) or seven hours (two pairs). During the experiments it was noted that diaphragms from plasmocid injected rats, when stained with methylene blue, failed to decolourize the dye as efficiently as control diaphragms. Conversion to leuko-methylene blue is produced by addition of $\mathrm{H}^{+}$to the dye molecule, and in living tissues this is dependent on dehydrogenase activity; this was therefore estimated by the Thunberg technique and by colorimetric determination of formazan formation (modification of the method described by Lee and Lardy, 1965). The results showed a variable decrease in $a$-glycerophosphate dehydrogenase ( $a$-GPD) activity, more marked in diaphragm than in other skeletal muscles. $a$-GPD was lower in the diaphragm of plasmocid as compared with saline injected animals in 24 of 28 pairs of rats killed two to seven hours after injection, though the mean decrease of $14 \%$ was not statistically significant. There was no evidence of leak of $a$-GPD either into blood or bathing fluid. Little change was found in lactate, malate, or succinate dehydrogenase activity.

It seemed possible that this decrease in $a$-GPD might be attributable to an effect on thiol groups for two reasons. Firstly, a decrease in $a$-GPD can be produced by loss of some of the 11 active $\mathrm{SH}$ groups on the enzyme molecule, as shown by Telegdi and Keleti (1964) working with enzyme from rabbit skeletal muscle. Secondly, because the haemolysis produced by primaquine, an 8-aminoquinoline antimalarial drug related to plasmocid, occurs in cells deficient in glucose-6-phosphate dehydrogenase, in which the initial low level of the sulphydryl containing peptide glutathione is reduced still further by exposure to the drug. Determination of protein and non-protein SH groups were therefore made on various rat tissues after intraperitoneal injection of plasmocid.

\section{METHODS}

RATS Male albino rats, 120 to $170 \mathrm{~g}$ allowed food and water ad libitum, were injected intraperitoneally as indicated. Blood was obtained by cardiac puncture under ether anaesthesia immediately before killing the rats by decapitation. Muscle was rapidly removed, and samples taken for histology were fixed in formalin and stained with haemotoxylin and eosin. Remaining muscle was washed in normal saline, dissected free from collagen and fat, blotted dry, scissor minced, weighed, diluted as indicated and homogenized in a ground glass conical homogenizer pre-cooled to $-20^{\circ} \mathrm{C}$.

INTRA-PERITONEAL INJECTIONS Plasmocid dihydroiodide (Aldrich Chemical Co. Inc., Milwaukee, Wis.) was diluted immediately before use in normal saline. Injections of $25 \mathrm{mg} / \mathrm{kg}$ body wt. given in $1 \mathrm{ml}$. sterile saline were shown to produce histological changes in diaphragm at eight hours similar to those described by previous workers. Doses larger than this made rats lethargic, weak, and tachypnoeic and occasionally produced sudden extension of back and limbs followed by death within a few minutes. The disease-inducing potency of plasmocid decreased despite storage in a desiccator in the dark at $-4^{\circ} \mathrm{C}$, but deterioration was prevented by freeze-drying in ampoules containing sufficient for one injection, sealing and storing as before. Doses of $34 \mathrm{mg} / \mathrm{kg}$ body wt. were given in all experiments except those in which observations were made at one to 23 hours; in these $24 \mathrm{mg} / \mathrm{kg}$ were given. Paired rats were given plasmocid or equivalent volumes of saline simultaneously, killed at the same time and all estimations carried out in duplicate, and in parallel. $d-l$ tocopherol acetate in aqueous dispersion was diluted in sterile saline and injected in doses of 0.66 to $4 \mathrm{mg}$ in a volume of $0.2 \mathrm{ml}$. Glutathione (GSH) was diluted 100 $\mathrm{mg} / \mathrm{ml}$. in sterile saline and doses of $660 \mathrm{mg}$ given 0 Ascorbic acid was diluted $8 \mathrm{mg} / \mathrm{ml}$. in $0.001 \mathrm{M}$ phosphate buffer $p \mathrm{H} \mathrm{7 \cdot 4}$, and doses of $32 \mathrm{mg} / \mathrm{kg}$ body weight given In experiments in which the rats received two injections four rats were used. Two rats were injected with toco $z$ pherol, GSH, or ascorbic acid, and two with an equivalenk volume of diluent. One hour later one rat from each pairo was given plasmocid, and the remaining two rats giver saline. The animals were killed two hours after the second injection.

Protein and non-protein thiol determination Diaphragm was washed in ice cold $0.9 \% \mathrm{KCl}$, homogenized $1 / 10$ $\mathrm{w} / \mathrm{v}$ in phosphate saline, centrifuged at $1,500 \mathrm{~g}$ for 10 minutes, and the estimation performed on $0.2 \mathrm{ml}$. of the supernatant as described by Jocelyn (1962), except that in the estimation of non-protein SH the optical density (O.D.) at $412 \mathrm{~m} \mu$ in $1 \mathrm{~cm}$ cells in a SP600 spectrophotometer was read $21 / 2$ minutes after addition of 5 , 5'dithiobis-(2-nitrobenzoic acid) (DTNB). Experiments showed that the O.D. was more stable at this time than at 30 seconds as recommended by Jocelyn (1962). Protein content of homogenate was determined using FolinCiocalteu phenol reagent as described by Lowry, Rosebrough, Farr, and Randall (1951), with standard protein solutions of egg albumen.

Non-protein thiol determination Non-protein $\mathrm{SH}$ was estimated on blood as described by Grunert and Phillips (1951). Diaphragm and heart muscle were homogenized $1 / 10 \mathrm{w} / \mathrm{v}$, and liver $1 / 30 \mathrm{w} / \mathrm{v}$, in $2.5 \%$ metaphosphoric acid (MPA). Solutions were used as described by Grunert, but the volumes reduced. To $0.4 \mathrm{ml}$. homogenate were added $0.2 \mathrm{ml}$. sodium nitroprusside and $0.2 \mathrm{ml} . \mathrm{Na}_{2} \mathrm{CO}_{3} /$ $\mathrm{NaCN}$ solution. Protein precipitated by MPA was taken up in $\mathrm{NaOH}$ and the protein content determined as described above

Oxidized glutathione estimation A modification of

(n)

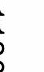


Klotzsch and Bergmeyer's technique (1963) was used on pooled diaphragm from two rats or on heart muscle, homogenized $1 / 3 \mathrm{w} / \mathrm{v}$ in $6 \%$ perchloric acid. The high O.D. of this homogenate at $240 \mathrm{~m} \mu$ precluded estimation of GSH as described by Klotzsch, and non-protein SH therefore, determined on diluted aliquots of homogenate by Grunert and Phillips' method (1951). Although the absorption spectrum of the homogenate indicated that the high O.D. was probably due to nucleotides, attempts to decrease this by treating with activated carbon and resins interfered with the method and were not satisfactory. Oxidized glutathione (GSSG) was estimated with solutions as described by Klotzsch, but only 0.02 ml. NADPH was used, since this gave an O.D. in the most sensitive range of the spectrophotometer (Unicam SP500) at $340 \mathrm{~m} \mu$. A spontaneous decline in O.D. of the homogenate and substrate mixture was shown (Fig. 1A). Addition of glutathione reductase (GSSGR) caused a transient increase in rate of decline (Fig. 1B), which was related to the amount of GSSG present (Fig. 1C). From observation of the initial rate of decline in O.D. the predicted O.D. 14 minutes later (R1 Figs. 1B and C) was calculated, and subtraction from this of the actual O.D. 14 minutes after enzyme addition (R2 Figs. 1B and C) gave the change in O.D. due to oxidation of NADPH by GSSGR, and was related to the amount of GSSG present.

Facilities were not available for thermostatic control of the cells during incubation; the estimations were therefore performed in parallel with an internal standard in the third cell which contained a sample of homogenate with additional $0.025 \mu$-mole GSSG.

Creatine phosphokinase (CPK) was estimated by the method of Hughes (1962).

\section{RESULTS}

(i) PROTEIN AND NON-PROTEIN THIOL AS DETERMINED BY JOCELYN'S METHOD Results are shown in Table I. Protein SH is seen to be unaffected by plasmocid, but by two hours after injection there is a highly significant fall in non-protein SH content of diaphragm both in relation to wet weight and to muscle protein content. Figure 2 shows levels of non-protein thiol expressed in terms of wet weight of muscle and related to rat body weight. The difference between control and plasmocid levels is shown, and also a tendency for non-protein SH content to increase with rat weight. In subsequent experiments therefore only rats weighing between 145 and $155 \mathrm{~g}$ were used.

(ii) NON-PROTEIN THIOL AS DETERMINED BY GRUNERT AND PHILLIPS' METHOD Jocelyn's method of nonprotein SH determination depends on readings taken while the O.D. is rising, a rise shown by Jocelyn to be due to breakdown of protein SH. The estimation was therefore repeated using Grunert's method which does not have this disadvantage, the determination being performed on protein free supernatant. Results on diaphragm, heart muscle, liver and blood, one to two hours after injection are shown in Table II. Again a highly significant decrease in non-protein $\mathrm{SH}$ is shown in diaphragm, and a similar decrease is seen in heart muscle, but

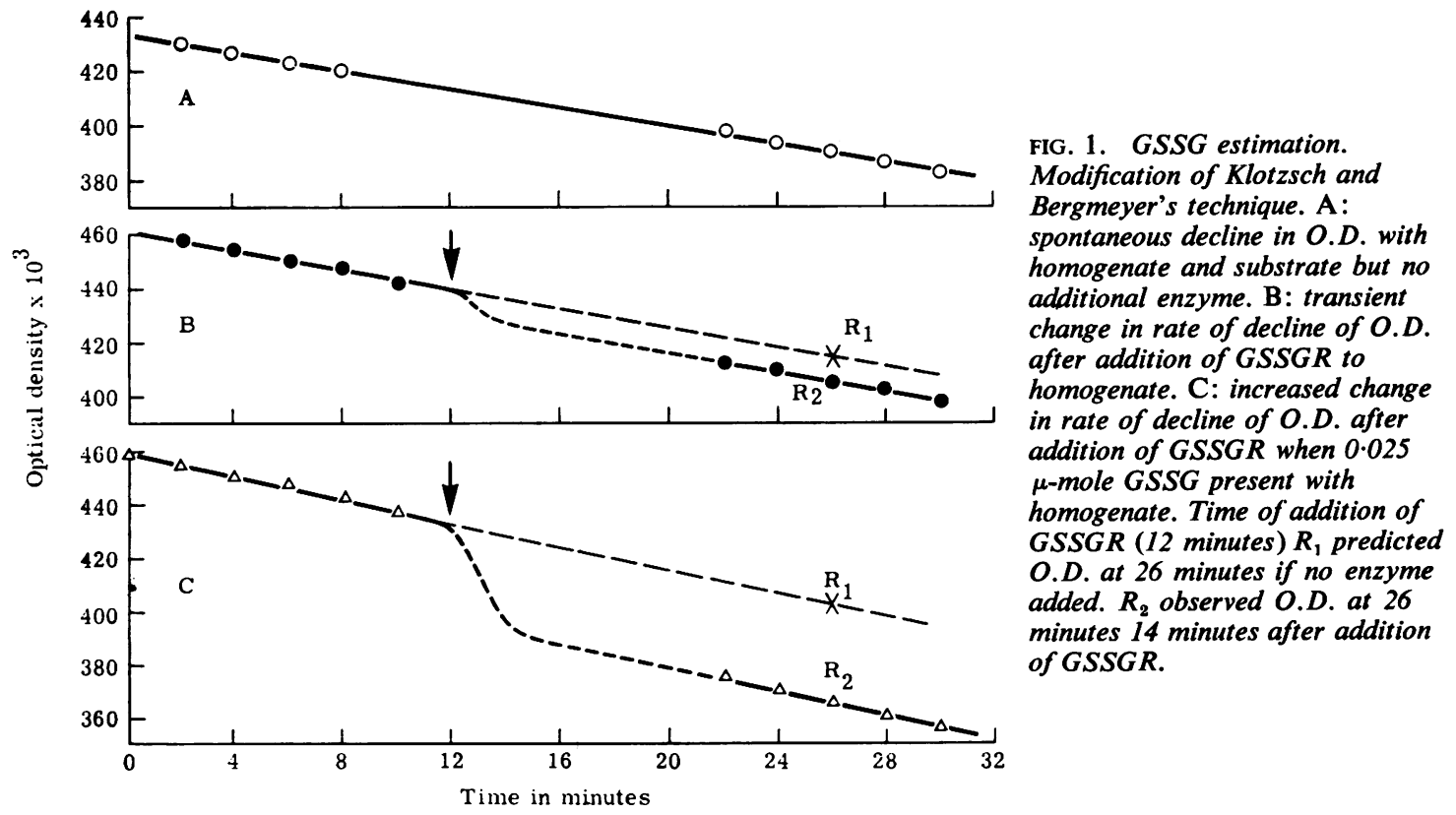


TABLE I

PROTEIN AND NON-PROTEIN THIOL DETERMINATION— JOCELYN'S METHOD

\begin{tabular}{|c|c|c|c|c|c|c|c|c|}
\hline & Non-protein & & & & Protein $S H$ & & & \\
\hline & $\begin{array}{l}\text { Control } \\
(\mu-\text { mole/g we }\end{array}$ & $\begin{array}{l}\text { Plasmocid } \\
t \text { wt.) }\end{array}$ & $\begin{array}{l}\text { Control } \\
(\mu-\text { mole/g } \mathrm{Pr}\end{array}$ & Plasmocid & $\begin{array}{l}\text { Control } \\
(\mu-\text { mole } / g w\end{array}$ & $\begin{array}{l}\text { Plasmocid } \\
\text { et wt.) }\end{array}$ & $\begin{array}{l}\text { Control } \\
(\mu-\text { mole/g Pr. }\end{array}$ & Plasmocid \\
\hline $\begin{array}{l}\text { Mean } \\
\text { S.E.M. }\end{array}$ & $\begin{array}{l}2 \cdot 10 \\
0 \cdot 11 \\
0.01>P>\end{array}$ & $\begin{array}{l}1.61 \\
0 \cdot 16 \\
0.001\end{array}$ & $\begin{array}{l}41.92 \\
2.9 \\
0.05>P>\end{array}$ & $\begin{array}{c}32.4 \\
3.6 \\
0.02\end{array}$ & $\begin{array}{l}1 \cdot 27 \\
0 \cdot 13\end{array}$ & $\begin{array}{l}1.28 \\
0.11\end{array}$ & $\begin{array}{r}25 \cdot 2 \\
2 \cdot 2\end{array}$ & $\begin{array}{r}25 \cdot 7 \\
2 \cdot 2\end{array}$ \\
\hline
\end{tabular}

Diaphragm two hours after plasmocid injection. Results expressed as $\mu$-mole of GSH. The means are of nine experiments.

TABLE II

NON-PROTEIN THIOL DETERMINATION BY GRUNERT AND PHILLIPS' METHOD

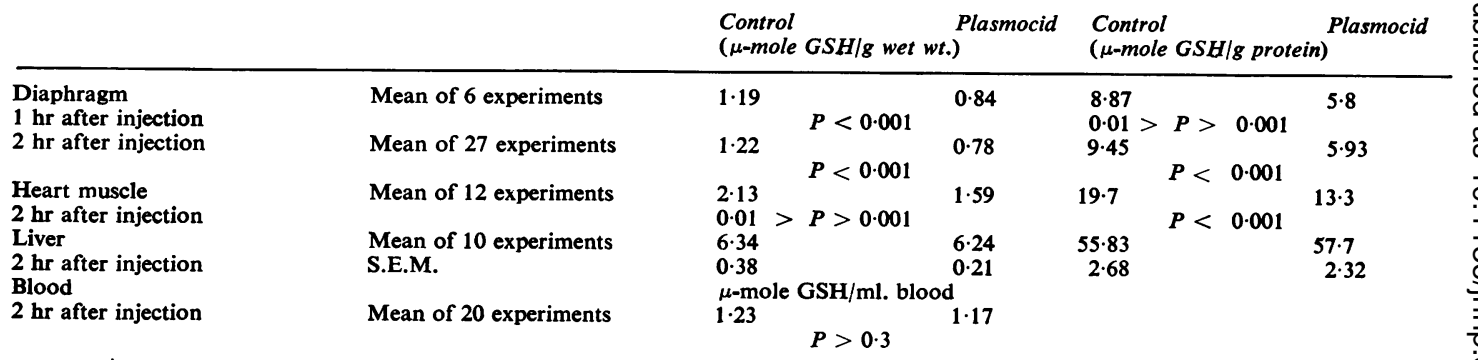

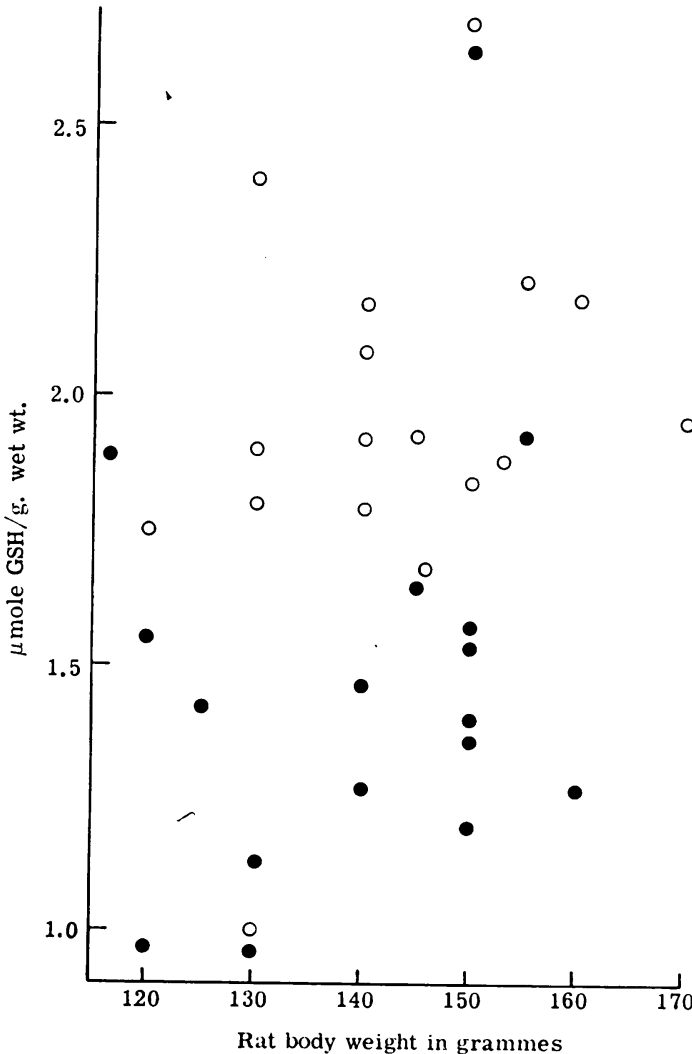

FIG. 2. Non-protein $\mathrm{SH}$ in diaphragm estimated by Jocelyn's method, results related to body weight. $\mathrm{O}=$ control, saline injected animals. $=$ plasmocid injected animals.

levels in liver and blood are unaffected. The higher $\vec{\sigma}$ values obtained using Jocelyn's method for nonvos protein SH in diaphragm is probably due in pas to breakdown of protein $\mathrm{SH}$. The difference is values between the two methods when the resulis are expressed in relation to protein is attributable to the fact that with Jocelyn's method results are related to protein content of the supernatant fluig after removal of debris containing some protein whereas in Grunert and Phillips' method results afe related to total precipitated protein.

Results of estimation of non-protein $\mathrm{SH}$ in diaphragm at intervals from one to 23 hours after plasmocid $24 \mathrm{mg} / \mathrm{kg}$ body wt. are shown in Figure 3 . Non-protein $\mathrm{SH}$ is seen to fall progressively to approximately half of the control at seven hours after plasmocid, and to return to normal levels by 23 hours.

Results of experiments in which rats were injected with either GSH, tocopherol or ascorbic acid one hour before injection with plasmocid and killed two hours after the second injection are shown in Table III. In the doses used none of these substances affects the non-protein SH content of diaphragm at three hours, and the decrease after plasmocid is not prevented. Non-protein SH levels in blood were unchanged in two rats three hours after injection of GSH.

(iii) GSSG DETERMINATION The figures in Table IV show that there is no increase in GSSG in plasmocid homogenate, although estimation of non-protein SH on samples of the same homogenate by Grunert 


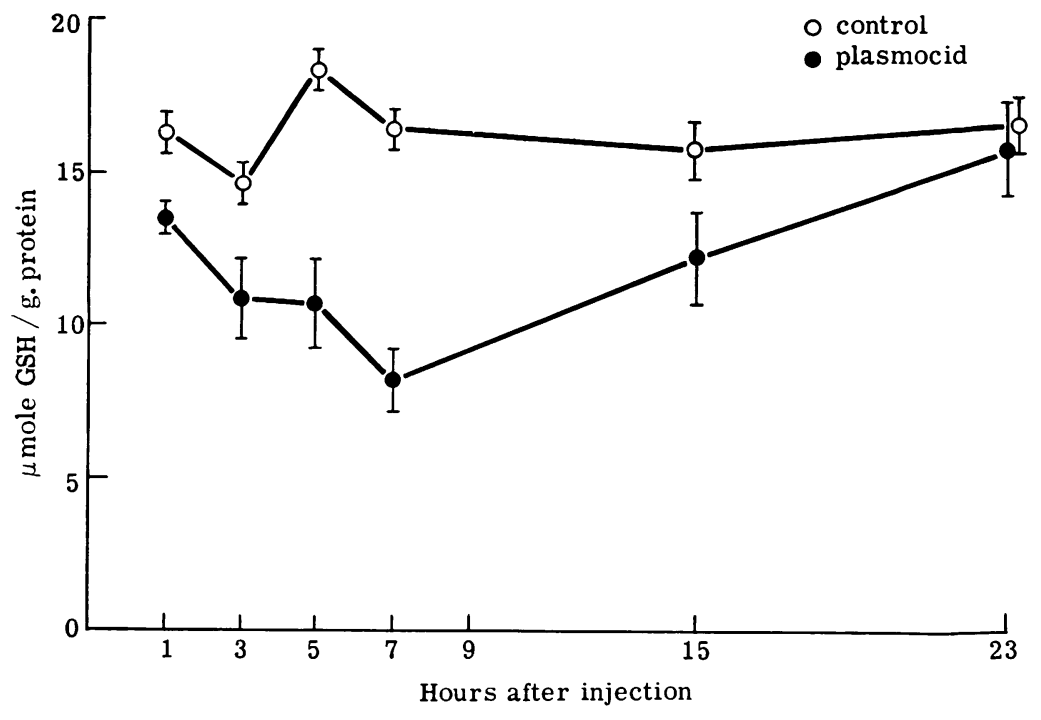

FIG. 3. Time sequence of change in non-protein $\mathrm{SH}$ in rat diaphragm after plasmocid. Estimation by Grunert and Phillips' method. Each point represents the mean of four determinations. Vertical lines $=2 \times$ S.E.M.

\section{TABLE III}

EFFECT ON DIAPHRAGM NON-PROTEIN SH OF INJECTION OF EITHER GSH, TOCOPHEROL OR ASCORBIC ACID, 1 HOUR BEFORE PLASMOCID OR SALINE INJECTION. (RATS KILLED 2 HOURS AFTER SECOND INJECTION)

\begin{tabular}{|c|c|c|c|c|c|c|c|c|c|c|}
\hline & & $\begin{array}{l}\text { 1st injection } \\
2 n d \text { injection }\end{array}$ & $\begin{array}{l}\text { Saline } \\
\text { Saline } \\
\mu \text {-mole G }\end{array}$ & $\begin{array}{l}\text { GSH } \\
\text { Saline } \\
\text { H/g wet wt }\end{array}$ & $\begin{array}{l}\text { Saline } \\
\text { Plasm. }\end{array}$ & $\begin{array}{l}\text { GSH } \\
\text { Plasm. }\end{array}$ & $\begin{array}{l}\text { Saline } \\
\text { Saline } \\
\mu \text {-mole } G\end{array}$ & $\begin{array}{l}\text { GSH } \\
\text { Saline } \\
\text { H/g protein }\end{array}$ & $\begin{array}{l}\text { Saline } \\
\text { Plasm. }\end{array}$ & $\begin{array}{l}\text { GSH } \\
\text { Plasm. }\end{array}$ \\
\hline \multirow[t]{2}{*}{ GSH dose } & $660 \mathrm{mg} / \mathrm{rat}$ & $\begin{array}{l}\text { Mean } \\
\text { S.E.M. }\end{array}$ & $\begin{array}{l}1 \cdot 73(6) \\
0.08\end{array}$ & $\begin{array}{l}1 \cdot 76(6) \\
0 \cdot 1\end{array}$ & $\begin{array}{l}1 \cdot 27(6) \\
0 \cdot 1\end{array}$ & $\begin{array}{l}1 \cdot 18(6) \\
0 \cdot 1\end{array}$ & $13 \cdot 9(2)$ & $13 \cdot 5(3)$ & $9 \cdot 5(3)$ & $10 \cdot 2(3)$ \\
\hline & & $\begin{array}{l}\text { 1st injection } \\
2 \text { 2nd injection }\end{array}$ & $\begin{array}{l}\text { Saline } \\
\text { Saline }\end{array}$ & $\begin{array}{l}\text { Tocoph. } \\
\text { Saline }\end{array}$ & $\begin{array}{l}\text { Saline } \\
\text { Plasm. }\end{array}$ & $\begin{array}{l}\text { Tocoph. } \\
\text { Plasm. }\end{array}$ & $\begin{array}{l}\text { Saline } \\
\text { Saline }\end{array}$ & $\begin{array}{l}\text { Tocoph. } \\
\text { Saline }\end{array}$ & $\begin{array}{l}\text { Saline } \\
\text { Plasm. }\end{array}$ & $\begin{array}{l}\text { Tocoph. } \\
\text { Plasm. }\end{array}$ \\
\hline \multirow[t]{2}{*}{ Tocopherol } & $\begin{array}{l}\text { lose } \\
0.66 \mathrm{mg} / \mathrm{rat} \\
1.0 \mathrm{mg} / \mathrm{rat} \\
2.0 \mathrm{mg} / \mathrm{rat} \\
3.0 \mathrm{mg} / \mathrm{rat} \\
4.0 \mathrm{mg} / \mathrm{rat}\end{array}$ & $\begin{array}{l}\text { Mean } \\
\text { S.E.M. } \\
\text { Mean }\end{array}$ & $\begin{array}{l}1.66(1) \\
1.46(1) \\
1.46(1) \\
1 \cdot 74(10) \\
0.06 \\
1 \cdot 70(2)\end{array}$ & $\begin{array}{l}1 \cdot 53(1) \\
1 \cdot 31(1) \\
1.49(1) \\
1.62(10) \\
0.06 \\
1 \cdot 76(2)\end{array}$ & $\begin{array}{l}0.71(1) \\
0.57(1) \\
0.73(1) \\
1.05(10) \\
0.07 \\
1.19(2)\end{array}$ & $\begin{array}{l}0.82(1) \\
0.68(1) \\
0 \cdot 84(1) \\
1 \cdot 10(10) \\
0.08 \\
1.06(2)\end{array}$ & $\begin{array}{c}11 \cdot 9(1) \\
10 \cdot 4(1) \\
11 \cdot 8(1) \\
14 \cdot 5(10) \\
0 \cdot 8 \\
12 \cdot 5(2)\end{array}$ & $\begin{array}{c}13 \cdot 0(1) \\
9 \cdot 2(1) \\
11 \cdot 6(1) \\
13 \cdot 9(10) \\
0 \cdot 7 \\
11 \cdot 7(2)\end{array}$ & $\begin{array}{l}6 \cdot 5(1) \\
4 \cdot 0(1) \\
5 \cdot 4(1) \\
9 \cdot 0(10) \\
0 \cdot 7 \\
8 \cdot 7(2)\end{array}$ & $\begin{array}{l}6 \cdot 7(1) \\
4 \cdot 9(1) \\
6 \cdot 0(1) \\
8 \cdot 8(10) \\
0 \cdot 5 \\
7 \cdot 1(2)\end{array}$ \\
\hline & & $\begin{array}{l}\text { 1st injection } \\
2 \text { 2nd injection }\end{array}$ & $\begin{array}{l}P . \\
\text { buffer } \\
\text { Saline }\end{array}$ & $\begin{array}{l}\text { Asc. } \\
\text { Acid } \\
\text { Saline }\end{array}$ & $\begin{array}{l}P . \\
\text { buffer } \\
\text { Plasm. }\end{array}$ & $\begin{array}{l}\text { Asc. } \\
\text { Acid } \\
\text { Plasm. }\end{array}$ & $\begin{array}{l}P . \\
\text { buffer } \\
\text { Saline }\end{array}$ & $\begin{array}{l}\text { Asc. } \\
\text { Acid } \\
\text { Saline }\end{array}$ & $\begin{array}{l}P . \\
\text { buffer } \\
\text { Plasm. }\end{array}$ & $\begin{array}{l}\text { Asc. } \\
\text { Acid } \\
\text { Plasm. }\end{array}$ \\
\hline \multicolumn{2}{|c|}{$\begin{aligned} \text { Ascorbic acid dose } \\
32.4 \mathrm{mg} / \mathrm{kg} \\
\text { body wt. }\end{aligned}$} & Mean & $\begin{array}{l}1 \cdot 68(4) \\
0 \cdot 15\end{array}$ & $\begin{array}{l}1 \cdot 57(4) \\
0 \cdot 12\end{array}$ & $\begin{array}{l}1.24(4) \\
0.06\end{array}$ & $\begin{array}{l}1.23(4) \\
0.07\end{array}$ & $\begin{array}{c}14 \cdot 5(3) \\
0.38\end{array}$ & $\begin{array}{c}13.6(3) \\
1.39\end{array}$ & $\begin{array}{c}11 \cdot 1(3) \\
0.26\end{array}$ & $\begin{array}{c}10.2(3) \\
0.66\end{array}$ \\
\hline
\end{tabular}

Figures in parentheses indicate number of experiments.

and Phillips' method showed a decrease in plasmocid muscle in every case, the mean fall being $0.4 \mu$-mole $\mathrm{GSH} / \mathrm{g}$ wet wt. Such a fall, if due to oxidation of GSH to GSSG, would result in an increase of 0.2 $\mu$-mole GSSG/g wet wt. muscle-that is, 0.032 $\mu$-mole in the $0.167 \mathrm{~g}$ muscle present in each cell in the estimation of GSSG. The results for the internal standard estimated in parallel with each pair of homogenates showed a change in O.D. due to the $0.025 \mu$-mole GSSG ranging from $20 \times 10^{-3}$ to $57 \times 10^{-3}$, with a mean of $35 \times 10^{-3}$. In some of these experiments the GSSG was added to plasmocid homogenate, and the results showed that this did not contain a substance interfering with the enzymic determination of GSSG.

(iv) CREATINE PHOSPHOKINASE Estimation in 29 saline injected rats established a mean value of 156 $\mathrm{m}$ i.u. with a normal range of 8 to 304 . In 35 plasmocid injected animals killed two hours after injection, 25 showed CPK levels above the normal range, in some rising to above $1400 \mathrm{~m}$ i.u.; nine had levels 
TABLE IV

GSSG ESTIMATION IN RAT MUSCLE 2 HR AFTER PLASMOCID OR SALINE INJECTION

\begin{tabular}{llc} 
& \multicolumn{2}{c}{$\begin{array}{c}\text { Change in } O . D . \times 10^{3} \text { due to } \\
\text { GSSG in } 0.167 \mathrm{~g} \text { wet wt. muscle } \\
\text { Control }\end{array}$} \\
\hline Diascle & 19 & 19 \\
& 27 & 20 \\
& 30 & 25 \\
& 23 & 0 \\
& 28 & 29 \\
Heart & 19 & 5 \\
& 18 & 10 \\
& 41 & 44
\end{tabular}

between 193 and 345, and one had a level of 71 m i.u.

(v) HISTOLOGICAL EXAMINATION No change was seen in diaphragm, heart, or liver examined within five hours of plasmocid injection. At seven hours, although large areas of diaphragm appeared normal, in some sections a few fibres had lost their striations, were slightly swollen and more eosinophilic than usual. By 15 hours necrosis of scattered fibres had occurred with white cell infiltration which was more intense by 23 hours.

\section{DISCUSSION}

It is clear that a marked decrease in the non-protein SH content of cardiac and skeletal muscle occurs within one to two hours of injection of plasmocid, at a time before any structural changes are apparent. Liver, which is structurally unaffected by plasmocid, shows no change in non-protein SH content. The decrease seen in muscle continues for seven hours, at which time levels are about half those of the controls; by 15 hours the levels are rising and by 23 hours they have returned to normal. The return to normal thus precedes the first signs of regeneration reported at 24 to 48 hours by Adams et al. (1962), but is also coincident with increasing and dense infiltration of necrotic muscle with white cells. It seems likely from estimation of GSH in human white blood cells (Hardin, Valentine, Follette, and Lawrence, 1954) and in rat spleen (Binkley, Christensen, and $\mathrm{Wu}, 1951$ ), that rat leukocyte GSH content is of the same order as that of muscle, and it is therefore possible that the return of nonprotein SH to normal may be due, in part, to the GSH content of the infiltrating white cells.

Although the increase in serum CPK shown in 25 of 35 rats indicates that increased muscle membrane permeability may occur within two hours of plasmocid injection, the normal blood non-protein SH levels at this time make it seem unlikely that the fall in muscle non-protein $\mathrm{SH}$ is due to loss from muscle to extracellular fluid, unless the fall had occurred only in diaphragm and did not affect other muscle, in which case any change due to loss of non-protein SH to blood would be too small to be detected. The results also show that plasmocid does not have a direct effect on non-protein $\mathrm{SH}$ in blood. The normal blood CPK found in a few rats at a time when non-protein $\mathrm{SH}$ in diaphragm had fallen may indicate that this fall in muscle precedes the membrane damage, but may merely reflect the varied and sometimes very limited amount of muscle which previous workers have found to be affected by plasmocid.

Bajusz et al. (1964) showed, by direct perfusion of muscle, that plasmocid itself had no direct effect on muscle, and it was suggested in 1946 (see Wiselogle) that the active plasmocid metabolite might be a quinonimine, a powerful oxidizing substance. It seems probable that plasmocid is metabolized in the liver, where concentrations of the drug are higher than in the heart (Wiselogle, 1946). The failure to show any change in non-protein $\mathrm{SH}$ in liver or in blood makes it unlikely that the loss seen in muscle is produced by a direct oxidative affect of a plasmocid metabolite. Ascorbic acid is a readily diffusible reducing agent which might possiblo $\omega$ combat any effect of the postulated oxidative plase 을 mocid metabolite, but would have no direct effect on non-protein SH present as GSH in the tissueso since GSH is the stronger reducing agent. Injection of ascorbic acid before plasmocid prevented neitheo the clinical effect of the plasmocid nor the fall ii muscle non-protein SH (Table III). Moreover, i muscle in which non-protein SH levels were shown to have decreased, no increase in GSSG was detected. In other tissues correspondence of results obtained by measuring non-protein $\mathrm{SH}$ with those measuring GSH have shown that practically all non-protein SH is GSH. GSH in cells is very readily oxidized to GSSG, and is kept in the reduced state by GSSGR; it seems likely, therefore, that if the fall in nonprotein SH in muscle were due to loss of GSH by oxidation then an increase in GSSG would have resulted.

Bowden and Goyer (1962) noted an increased secretion of taurine, maximal at two hours after plasmocid, with a mean excretion of $28 \mu$-mole/24 hours $100 \mathrm{~g}$ of rat in 150 to $250 \mathrm{~g}$ rats-that is, approximately $0.8 \mu$-mole $/ \mathrm{g}$ muscle, a figure in the same range as the observed fall in non-protein SH in the first $\mathbf{2 4}$ hours after plasmocid injection. It is possible that at least some of this taurine may be formed from muscle GSH, since enzymes catalysing the hydrolysis of GSH to its constituent amino acids (which include cysteine) have been found in various tissues; cysteine may be converted to cysteic 
acid by an oxidizing agent, and enzymic decarboxylation of cysteic acid produces taurine.

The significance of the observed decrease in nonprotein $\mathrm{SH}$ in relation to the subsequent change in cell structure is obscure. Bowden and Goyer (1962) noted that taurinuria was a feature of tissue necrosis due to a number of different causes, and concluded that it was a non-specific indication of protein catabolism rather than an indication of abnormal SH amino-acid metabolism produced by plasmocid. It is possible that the fall in SH may also be a nonspecific early step or side-effect in the series of biochemical events leading to necrosis from other causes. GSH has been implicated in the maintenance of cell structure in a variety of contexts. For example, GSH may protect cells from necrosis caused by radiation, by dietary deficiency, or by chemicals; the GSH content of erythrocytes may be correlated with their ability to resist haemolysis (Fegler, 1952) and it falls with loss of cell structure (Beutler, Dern, Flanagan, and Alving, 1955), a fall also shown in liver cells damaged either by dietary deficiency or by venous congestion (Lindan and Work, 1953).

Although it is widely distributed in plant and animal tissues the role of GSH in cell metabolism is still unknown. By virtue of its ready conversion to GSSG and reconversion to GSH, GSH may act as a buffer protecting the thiol groups of larger molecules, particularly the protein thiol groups which are of importance in enzyme activity, in protein structural stability and membrane permeability. Although no change in protein $\mathrm{SH}$ was detected two hours after plasmocid, it is possible that a decrease might occur later when structural changes appear, and also that some protein $\mathrm{SH}$ could have been lost earlier without any detectable overall change in reactive protein thiol. Thus, loss of protein SH may affect the stability of protein, as was shown by Aronson (1966) who demonstrated that loss of SH groups from myosin resulted in denaturation at body temperature. Such an initial decrease in SH may be masked, since many proteins contain SH groups which are protected from reaction by configuration and by local charges and these become exposed and therefore reactive when the protein is denatured. Furthermore with alteration of protein structure intra-molecular S-S linkages may break and result in the formation of new SH groups. An initial loss of protein $\mathrm{SH}$ could thus precipitate a change in protein structure, and resultant exposure of previously non-reactive $\mathrm{SH}$ groups and formation of new ones from S-S linkages could mask the early SH loss. Once denaturation has occurred GSH is able to react with intramolecular S-S bonds, and such a reaction would accelerate both loss of GSH and breakdown of protein.
Attempts to maintain non-protein SH levels in muscle after plasmocid by injection of GSH were unsuccessful. Three hours after injection no change was seen in GSH content of blood or muscle, and the fall induced by plasmocid was unaffected. The fate of GSH after injection is not known; Binkley et al. (1951) state that it is taken up by kidney and intestine, but give no figures to support this. Doses used in the present experiments, up to $660 \mathrm{mg}$ given one hour before plasmocid, were based on those found to be tolerated in animals by Binkley et al. However, Lazarow (1946) found that four times this dose was required to protect against alloxan, and protection against both alloxan and radiation has also been obtained by injection of GSH given within a few minutes of exposure. It would therefore be of interest to observe the affect of larger doses of GSH given at the same time as plasmocid.

Corwin and Schwartz (1963) provided evidence compatible with their suggestion that tocopherol may act by protecting thiol groups. In the doses used here, doses based on the work of Rodnan, Chernick, and Schwartz (1956), tocopherol afforded no protection against the fall in muscle GSH induced by plasmocid.

It is noteworthy that the present results for nonprotein $\mathrm{SH}$ in diaphragm ( $60 \mathrm{mg} \mathrm{GSH} / 100 \mathrm{~g}$ wet wt.) are considerably higher than those obtained in other skeletal muscle by Binkley et al. (1951) (13 mg GSH/100 g wet wt.), and by Hooton and Watts (1967), (15 mg/100 $\mathrm{g}$ wet wt.). This difference is unlikely to be due entirely to differences in technique, since Hooton and Watts used the same method of estimation as the present work, and the results of Binkley et al. for GSH in tissues other than diaphragm do not show such a marked discrepancy. Thus, Binkley's results for cardiac muscle $(42 \mathrm{mg} /$ 100 wet wt.) and liver $(128 \mathrm{mg} / 100 \mathrm{~g}$ wet wt.) are only $36 \%$ lower than the present work (66 and 200 $\mathrm{mg} / 100$ wet wt.) respectively. The present results for liver agree with those of Lindan and Work (1953) and with Bhattacharya, Robson, and Stewart (1955). No other estimations of GSH in diaphragm have been reported. It seems possible that high GSH levels may be associated with repetitive muscle contraction, the levels being higher in diaphragm than in other skeletal muscles, and higher still in cardiac muscle, the most continuously active muscle in the body.

\section{SUMMARY}

Although preliminary experiments using rat diaphragm showed no significant change in either aerobic or anerobic glycolysis in the interval between plasmocid injection and the appearance of structural 
changes, there was a variable decrease in $a$-GPD. This finding led to the study of SH compounds which showed that within one to two hours of injection there was a significant decrease in non-protein $\mathrm{SH}$ in diaphragm and heart muscle. No such change was detected in liver, which plasmocid does not affect structurally. The fall in muscle non-protein SH continued to about half the control levels by seven hours, when structural changes first appeared, and then returned to normal levels by 23 hours. The decrease was not accompanied by any detectable change in protein SH, nor by any increase in GSSG. In many but not all rats, the serum CPK had risen two hours after plasmocid, but non-protein SH levels in blood remained unchanged. Injection of GSH, tocopherol or ascorbic acid one hour before plasmocid did not affect the subsequent fall in nonprotein $\mathrm{SH}$ in diaphragm.

This work was supported by a grant from the Medical Research Council, and forms part of a thesis submitted for the degree of M.D. in the University of London. I would like to thank Dr. Brian McArdle, to whom I am most grateful for his constant help, guidance and advice, and Mr. A. E. Taylor and Mr. J. Whistler for their technical assistance.

\section{REFERENCES}

Adams, R. D., Denny-Brown, D., and Pearson, C. M. (1962). Diseases of Muscle. A Study in Pathology. 2nd ed., pp. 220-227. Henry Kimpton, London.

Aronson, J. F. (1966). Proposed mechanism for the turnover of myosin and its relation to muscular dystrophy. Nature (Lond.), 210, 995-996.

Bajusz, E., and Jasmin, G. (1963). Comparative morphogenesis and enzyme histogenesis of some occlusive and metabolic cardiac necroses. Rev. canad. Biol., 22, 181-199.

- - - and Mongeau, A. (1964). Dissociation by forced muscular exercise of the cardiotoxic from the myotoxic actions of plasmocid. Ibid., 23, 29-36.

Balogh, K., Prágay, D. A., and Hoyt, R. F. (1967). Myocardial enzymes in plasmocid poisoned rabbits. A correlative histochemical and biochemical study. Lab. Invest., 16, 211-219.

Beutler, E., Dern, R. J., Flanagan, C. L., and Alving, A. S. (1955) The hemolytic effect of primaquine VII Biochemical studies of drug-sensitive erythrocytes. J. Lab. clin. Med., 45, 286-295.

Bhattacharya, S. K., Robson, J. S., and Stewart, C. P. (1955). The determination of glutathione in blood and tissues. Biochem. J., 60, 696-702.

Binkley, F., Christensen, G. M., and Wu, F. C. (1951). Metabolism of glutathione. V. An effect of insulin. J. biol. Chem., 192, 29-34.
Bowden, D. H., and Goyer, R. A. (1962). Drug-induced muscle $\bar{Z}$ necrosis with massive taurinuria. Arch. Path., 74, 137-141.

Corwin, L. M., and Schwarz, K. (1963). Relation of tocopherol to enzyme sulfhydryl sites. Arch. Biochem., 100, 385-392.

Fegler, G. (1952). Relationship between reduced glutathione content and spontaneous haemolysis in shed blood. Nature (Lond.), 170, 624-625.

Fourneau, E., Tréfouel, J., Bovet, D., and Benoit, G. (1931). Con- To tribution á la chimiothérapie du Paludisme essais sur les calfats. Ann. Inst. Pasteur, 46, 514-541.

Goyer, R. A., Yin, M. W., and Bowden, D. H. (1964). Taurine excretion following drug-induced muscle necrosis and $X-$ irradiation. Proc. Soc. exp. Biol. (N.Y.), 116, 534-536.

Grunert, R. R., and Phillips, P. H. (1951). A modification of the nitro prusside method of analysis of glutathione. Arch. Biochem., 30, 217-225.

Hardin, B., Valentine, W. N., Follette, J. H., and Lawrence, J. S. (1954). Studies on the sulf hydryl content of human leukocytes and erythrocytes. Amer. J. med. Sci., 228, 73-82.

Hicks, S. P. (1950). Brain metabolism in vivo. II. The distribution of lesions caused by azide, malonitrile, plasmocid and dinitrophenol poisoning in rats. Arch. Path., 50, 545-561.

Hooton, B. T., and Watts, D. C. (1967). Levels of protein and nonprotein sulphydryl groups in the skeletal muscle of normal and dystrophic Bar Habor mice. Clinica Chim. Acta, 16, 173. 176.

Hughes, B. P. (1962). A method for the estimation of serum creatine kinase and its use in comparing creatine kinase and aldolase activity in normal and pathological sera. Ibid., 7, 597-603.

Jocelyn, P. C. (1962). The effect of glutathione on protein sulphydryl groups in rat-liver homogenates. Biochem. J., 85, 480-485.

Klotzsch, H., and Bergmeyer, H. U. (1963). Glutathione, pp. 363-366 in Methods of Enzymatic Analysis, edited by H. U. Bergmeyer. Academic Press, New York and London.

Lazarow, A. (1946). Protective effect of glutathione and cysteinto against alloxan diabetes in the rat. Proc. Soc. exp. Biol. (N.Y. $\delta$ 61, 441-447.

Lee, Y. P., and Lardy, H. A. (1965). Influence of thyroid hormones oه 1-a-glycerophosphate dehydrogenases and other dehydro genases in various organs of the rat. J. biol. Chem., 240, 1427 1436 .

Lindan, O., and Work, E. (1953). Experimental liver necrosis in rats. Biochem. J., 55, 554-566.

Lowry, O. H., Rosebrough, N. J., Farr, A. L., and Randall, R. (1951). Protein measurement with the Folin phenol reagent J. biol. Chem., 193, 265-275.

Mommaerts, W. F. H. M., Illingworth, B., Pearson, C. M., Guillor R. S., and Seraydarian, K. (1959). A functional disorder of muscle associated with the absence of phosphorylase. Proc. nat. Acad. Sci. (Wash.), 45, 791-797.

Price, H. M., Pease, D. C., and Pearson, C. M. (1962). Selective actin filament and Z-band degeneration induced by plasmocid. An electron microscopic study. Lab. Invest., 11, 549-562.

Rodnan, G. P., Chernick, S. S., and Schwarz, K. (1956). Reversal of respiratory decline in necrotic liver degeneration by intraportal tocopherols. J. biol. Chem., 221, 231-238.

Telegdi, M., and Keleti, T. (1964). The role of sulphydryl groups in a-glycerophosphate dehydrogenase. (L-glycerol-3-phosphate: NAD oxidoreductase 1.1.1.8) activity. Acta. physiol. Acad. Sci. hung., 25, 181-189.

Wachstein, M., and Meisel, E. (1955). Succinic dehydrogenase activity in myocardial infarction and in induced myocardial necrosis. Amer. J. Path., 31, 353-365.

Wiselogle, F. Y. (1946). Survey of Antimalarial Drugs, pp. 73-175. Vol. 1. Edwards, Ann. Arbor, Michigan. 